\title{
ANALISA YURIDIS PENCABUTAN HAK MEMILIH DAN DIPILIH SEBAGAI PIDANA TAMBAHAN DALAM PERSPEKTIF PERLINDUNGAN HAK ASASI MANUSIA PADA PUTUSAN RATU ATUT CHOSIYAH
}

Oleh:

\author{
I Wayan Dharma Na Gara ${ }^{1}$
}

\begin{abstract}
The idea on this jurnal is the analyzing of the rule regarding the disenfranchisement as an additional sentence in the perspective of Human Rights protection on Ratu AtutChosiyah's verdict, which is based on the conflict of norm between Law Number 39 Year 1999 Regarding The Human Rights (UU HAM) jo., Law Number 12 Year 2005 Regarding The Ratification of ICCPR (UU ICCPR) against Law Number 1 Year 1946 Regarding Indonesian Criminal Code jo., Law Number 31 Year 1999 Regarding The Eradication of Corruption Act. The Method for this research is normative legal research due to the conflict of norms based above mentioned. Thus the additional sentences which were given by the judges of Supreme Court isstill tend to premature/unlawful from the perspective of Human Rights Regulation in Indonesia. In order to prevent the futurepremature/ unlawful of additional sentence of disenfranchisement whichgiven by the judges, a condition is required by UU ICCPR, it is the official emergencyannouncement of the state due to corruption by the Government.
\end{abstract}

Keywords: Disenfranchisement, Ratu AtutChosiyah's Verdict, Protection of Human Rights.

\begin{abstract}
Abstrak
Ide dari jurnal ini adalah menganalisa mengenai peraturan terkait pencabutan hak memilih dan dipilih sebagai pidana tambahan dalam perspektif perlindungan HAM pada putusan Ratu Atut Chosiyah, yang mana di dasari atas adanya konflik norma antara UU No. 39 Tahun 1999 Tentang HAM (UU HAM) jo., UU No. 12 Tahun 2005tentang Pengesahan ICCPR (UU ICCPR) terhadap KUHP jo., UU No. 31 Tahun 1999 Tentang Pemberantasan Tindak Pidana Korupsi (UU PTPK). Metode penulisan pada penelitian ini adalah yuridis normatif dikarenakan terdapat konflik norma sebagaimana disebutkan di atas, sehingga putusanpidana tambahan yang mana diberikan oleh Majelis Hakim pada tingkat kasasi masih cenderung prematur/cacat hukumjika ditinjau dari perspektif pengaturan HAM di Indonesia. Agar putusan pidana tambahan pencabutan hak memilih dan dipilih tersebut tidak prematur/cacat hukum maka suatu syarat diwajibkan oleh UU ICCPR yaitu pengumuman resmi darurat korupsi oleh pemerintah mesti dipenuhi.

Kata Kunci: Pencabutan hak memilih dan dipilih, putusan Ratu Atut Chosiyah dan perlindungan HAM.
\end{abstract}

Mahasiswa Magister Ilmu Hukum Universitas Udayana, Denpasar, Bali. Alamat Jl. PB. Jendral Sudirman Denpasar-Bali, e-mail: nagaralawyer@gmail.com. 


\section{PENDAHULUAN}

\subsection{Latar Belakang}

Indonesia merupakan negara yang berdasar atas Pancasila dan UUD 1945 yang terimplementasi dalam peraturan perundang-undangannya dimana segala hal yang berhubungan dengan Negara Kesatuan Republik Indonesia adalah berdasarkan atas aturan yang konkret, sehingga Republik Indonesia adalah negara hukum dimana pemerintahan diselenggarakan oleh dan untuk rakyat serta dimana pemerintah dan rakyat kedudukannya setara. Pengakuan Hak asasi manusia menjadi hal yang penting bagi Indonesia, seiring dengan sejarah politik bangsa Indonesia sebagai bangsa yang terjajah oleh karenanya pengakuan terhadap Hak Asasi Manusia menjadi dasar dalam penyelenggaraan negara serta dasar fundamental aturan yang berlaku di Indonesia. Seiring dengan perkembangan zaman dan peradaban tak dapat dipungkiri Indonesia mengalami banyak tantangan dan perubahan terlebih dari sisi pemerintahan begitu pula terhadap pengakuan dan pengaturan tentang Hak Asasi Manusia dalam kehidupan berbangsa dan bernegara. Ratifikasi ICCPR merupakan salah satu dampak dari perubahan tersebut dimana di dalamnya pengakuan terhadap Hak Asasi Manusia berupa Hak-hak Sipil Politik dari tiap individu menjadi fokus utama dari isi undang-undang iniselain itu sebelumnya Pasal 28D UUD 1945 juga menegaskan pada intinyabahwa setiap individu mempunyai supremasi hukum dan pengakuan terhadap asas equity before the law.

Indonesia mengalami perubahan signifikan sejak tumbangnya era orde baru digantikan dengan era reformasi sejak 1997 yang tidak saja membawa hawa segar bagi supremasi hukum danpengakuan sertapenegakan HAM tetapi juga membawa efek negatif, salah satu efek negatif yang paling merusak seluruh tatanan bangsa adalah tindak pidana korupsi yangbelakangan ini semakin canggih, masif dan sporadik. Korupsi,seolah menjadi tren di kalangan anggota legislatif maupun para pejabat publikdi negara ini. Agar lebih mengenal istilah korupsi berkatalah Fockema Andreae bahwa kata korupsi berasal dari bahasa Latin corruptiodan bahasa Belanda yaitu corruptive (korruptie) yang dalam bahasa Indonesia berarti korupsi. ${ }^{2}$

Pidana tambahan dalam hal pencabutan hak memilih dan dipilih baru-baru ini mendapat perhatian dari Para Majelis Hakim dalam putusannya terhadap perkara korupsi dikarenakan pidana denda dan pengembalian aset negara belum juga dirasakan mengakomodir rasa keadilan rakyat apalagi ketika terpidana korupsi tersebut kemudian mencalonkan menjadi anggota legislatif dan terpilih dalam pemilihan umum. Menyikapi fenomena tersebut, hukum hendaknya

Andi Hamzah, 2005, Pemberantasan Korupsi Melalui Hukum Pidana Nasional dan Internasional, Raja Grafindo Persada, Jakarta, hlm. 4. 
melindungi kepentingan manusia yang merupakan pedoman bagaimana manusia bertindak. ${ }^{3} \quad$ Hukum menghendaki stabilitas dan keadilan dalamsuatu tatahukummasyarakatyang bebas, yang di dalamnya orang-orang dapat hidup dengan hak mendapat perlakuan sama sebagai warga negara yang mandiri. ${ }^{4}$ Dasar pencabutan hak memilih dan dipilih sudah jelas diatur dalam Psl 10hrf b Nomor 1 dan Psl 35 (1) No. 3 KUHP jo., Psl 18 (1) hrf dUU PTPK, tetapi begitu negara berhadapan dengan entitas individu yang esensinya memiliki hak yang dijamin dan diatur dalam UUD ataupun UU HAM jo., UU ICCPR, disanalah pemerintah dalam hal ini lembaga yudikatif seharusnya bertindak pasif.

Mochtar Kusumaatmadja pernah berkata, tujuan hukum berlandaskan cita-hukum Pancasila ialah melindungi manusia Indonesia secara tidak langsung (negatif) dengan cara melakukan pencegahan terhadap tindakan sewenang-wenang pemerintah dan secara langsung (positif) dimana intinya yakni agar pengakuan dan penerapan terhadap HAM dan Kekuasaan Pemerintah dapat berjalan secara selaras dan seimbang.... ${ }^{5}$

3 Al. Wisnubroto dan G. Widiartana, 2005, Pembaharuan Hukum Acara Pidana, PT. Citra Aditya Bakti, Bandung, hlm.1.

4 B. Arief Sidharta, 2009, Meuwissen Tentang Pengembanan Hukum, Ilmu Hukum dan Filsafat Hukum, PT. Refika Aditama, Bandung, hlm. 68.

5 Titik Triwulan Tutik, 2006, Pengantar Ilmu Hukum, Prestasi Pustaka, Jakarta, hlm. 33.
Keselarasan dan keseimbangan dari HAM sebenarnya telah tercermin dari regulasi HAM di Indonesia dimana setiap manusia memiliki hak-hak yang melekat pada hakikat dan eksistensinya sebagai makhluk ciptaan Tuhan bukan serta merta pemberian dari negara, pemerintah, atau kaum yang berkuasa kepada warga negaranya tetapi murni karena hakekatnya sebagai manusia dan merupakan pemberian dari Tuhan. Karena itu segala bentuk diskriminasi terhadap HAM manusia satu dengan lainnya dalam bidang apapun adalah suatu kekeliruan besar. Tidak satupun manusia yang boleh dikhususkan terhadap manusia lainnya dalam kehidupan bermasyarakat di belahan dunia manapun hal tersebut berlaku sama.

Menelisik kembali ke sejarah masa lalu mengenai HAM, pengakuan mengenai HAM tidak terlepas dari sejarah revolusi Perancis dan perjuangan kemerdekaan rakyat Amerika yang memiliki kesamaan ciri tetapi ada satu hal yang membedakan diantara keduanya. Amerika, dimana banyak koloni yang memberontak dengan tujuan menjadi suatu bangsa yang tidak saja merdeka tetapi juga berdaulat, kaum revolusi Perancis juga berjuang untuk merubuhkan sistem pemerintahan kerajaan yang absolut dan tua dengan tujuan mendirikan suatu orde baru yang demokratis. Sejarah tersebut menunjukkan bahwa batas-batas pelaksanaan hak hanya akan ditetapkan atau dicabut oleh undang-undang. Hal ini dapat 
dilihat sebagai bagian konsep rule of law dimana beberapa kriteria harus dipenuhi bahwa hak harus jamin oleh suatu peraturan/undang-undang dan wajib mematuhi persyaratan hukum yang konstitusional. Konsep ini juga mewajibkan pemerintah yang berdaulat bertindak selaras dengan peraturan perundangan dan peraturan perundangan yang dijadikan dasar mengambil keputusan oleh pemerintah tersebut tidak boleh bersifat menindas, diskriminatif atau sewenang-wenang. ${ }^{6}$

Sudah menjadi pengetahuan umum bahwa konsep hak asasi manusia di tiap-tiap negara adalah berbeda, terlebih pada pelaksanaannya tidak bisa terlepas dari sistem perpolitikannya. Oleh karenanya Gunawan Muhammad dan Umar Kayam berpendapat, nilai budaya daerah pada tiap negara-negara yang berkembang bisa digali untuk menyokong unsur-unsur HAM. ${ }^{7}$ Untuk itu, nilai asasi yang dimiliki oleh setiap bangsa perlu dipakai sebagai landasan pokok di dalam mengambil keputusan, sehingga tidak timbul suatu persepsi bahwa HAM semata-mata hasil budaya asing yang dipaksakan, justru semua manusia itu pada dasarnya adalah sama dimana HAM yang diakui di suatu negara adalah berdasarkan filterisasi dari nilai-nilai yang hidup di negara tersebut.

6 Scott Davidson, 2008, Hak Asasi Manusia: Sejarah, Teori Dan Praktek Dalam Pergaulan Internasional Terjemahan A. Hadnyana Pudjaatmaka, Grafiti, Jakarta, hlm. 7.

7 Masyur Effendi, 2012, Dimensi/Dinamika Hak Asasi Manusia Dalam Hukum Nasional dan Internasional, Ghalia Indonesia, Jakarta, hlm. 47.
Hak yang mana di dalamnya tidak saja hanya terkandung elemen perlindungan dan kepentingan hukum tetapi hak juga mengandung elemen kehendak. Sebagai contoh, seseorang petani memiliki sepetak tanah, makahukum memberikan hak kepada si petani dalam arti bahwa kepentingan dia atas tanah tersebut dilindungi. Dia bebas berkehendak dengan tanah yang ia miliki tersebut.

Menurut Fitzgerald, ciri-ciri hak yang melekat pada hukum adalah:

1. Hak itu melekat pada diri pribadi orang per orang sebagai individu atau pemilik dari hak itu. Ia pundikatakan sebagai seorang yang mempunyai hak khusus atas dirinya terhadap barang yang dimilikinya;

2. Hak itu dimaksudkan kepada orang lain, yaitu yang menjadi pemegang kewajiban. Antara hak dan kewajiban terdapat hubungan korelatif.

3. Setiap hak menurut hukum mempunyai sebutan/gelar, yang mana suatu peristiwa yang menjadi alasan terekatnya hak tersebut kepada orang tersebut. ${ }^{8}$ Undang-undang HAM sebenarnya telah melindungi hak memilih dan dipilih tersebut baik pada Pasal 23 ayat (1), Pasal 26 ayat (2), Pasal 43 ayat (1), Pasal 73 dan 74 jo., Pasal 28 D ayat (3) UUD 1945 jo., Pasal 4, Pasal 5 dan Pasal 25 Pengesahan ICCPR.

8 Muhammad Siddiq Tgk. Armia, 2008, Perkembangan Pemikiran Teori Ilmu Hukum, PT. Pradnya Paramita, Jakarta, hlm. 61. 
Berdasarkan latar belakang masalah dalam penelitian ini, maka rumusan masalah yang dapat dikemukakan dalam penelitian ini yaitu sebagai berikut:

\subsection{Perumusan Masalah}

1. Apakah pencabutan hak memilih dan dipilih sebagai pidana tambahan sudah sesuai dengan perspektif perlindunganHak Asasi Manusia di Indonesia?

2. Apakah pencabutan hak memilih dan dipilih Ratu Atut Chosiyah sudah mencerminkan keadilan?

\subsection{Tujuan Penelitian}

Adapun tujuan penelitian ini adalah sebagai berikut:

1. Untuk menganalisis secara mendalam mengenai pengaturan perlindungan Hak Asasi Manusia terhadap maraknya pencabutan hak memilih dan dipilih pada terpidana kasus korupsi di Indonesia.

2. Untuk menganalisis secara mendalamunsur keadilan dalam pencabutan hak memilih dan dipilih dari putusan kasasi Ratu Atut Chosiyah.

\section{METODE PENELITIAN}

\subsection{Jenis Penelitian}

Jenis penelitian ini menggunakan metode penelitian yuridis normatif. Metode yuridis Normatif yang sering juga disebut sebagai penelitian doktrinal (doctrinal research) yaitu merupakan suatu penelitian yang mengacu pada analisis hukum, baik dalam arti law which is written in the regulation, maupun dalam arti law which was decided by judges thru judicial procedures. ${ }^{9}$ Sebagaimana dikatakan Ronny Hanitijio Soemitro bahwa penelitian hukum normatif atau penelitian hukum doktrinal adalah suatu penelitian hukum yang mana menggunakan sumber data sekunder/data yang diperoleh melalui bahan-bahan yang diperoleh dari perpustakaan/kepustakaan. ${ }^{10}$

Berdasarkan penjelasan tersebut diatas maka penelitian tentang Analisa Yuridis Pencabutan Hak Memilih Dan Dipilih Sebagai Pidana Tambahan Dalam Perspektif Hak Asasi Manusia Pada Putusan Ratu Atut Chosiyah adalah penelitian hukum normatif, karena penelitian ini berangkat dari pemikiran bahwa pencabutan hak memilih dan dipilih sebagaimana diatur dan dilindungi oleh UU HAM jo., UU ICCPR bertentangan dengan KUHP jo., UU PTPK yang perlu mendapatkan analisis hukum yang lebih mendalam dari segi regulasinya.

\footnotetext{
Ronald Dworking, 1973, Legal Research, Daendalus, h. 250, dalam Yenti Garnasih, 2003, Kriminalisasi Pencucian Uang (Money Laundering), Program Pasca Sarjana Fakultas Hukum Universitas Indonesia, Jakarta, hlm. 40.

10 Mukti Fajar ND dan YuliantoAchmad, 2007, Dualisme Penelitian Hukum, Fakultas Hukum Universitas Muhammadiyah, Yogyakarta, hlm. 109.
} 
III. HASIL DAN PEMBAHASAN

3.1 Tinjauan Umum Hak Memilih dan Dipilih, Pidana Tambahan, Hak Asasi Manusia.

Hak Memilih menurut Undangundang No. 8 Tahun 2012 Tentang Pemilihan Umum (UU MD3) Anggota DPR, DPD dan DPRD pada pasal 19 dan pasal 20 menyebutkan:

Pasal 19

(1) Warga Negara Indonesia yang pada hari pemungutan suara telah genap berumur 17 (tujuh belas) tahun atau lebih atau sudah/pernah kawin mempunyai hak memilih.

(2) Warga Negara Indonesia sebagaimana dimaksud pada ayat (1) didaftar 1 (satu) kali oleh penyelenggara Pemilu dalam daftar Pemilih.

Pasal 20

Untuk dapat menggunakan hak memilih, Warga Negara Indonesia harus terdaftar sebagai Pemilih kecuali yang ditentukan lain dalam Undang-Undang ini.

Selain dari hal tersebut, baik KUHP maupun perundang-undangan lain di luar dari KUHP tidak memberi penjelasan yang rinci mengenai hak memilih dan dipilih sehingga pengertian hak memilih dan dipilih diambil dari Kamus Besar Bahasa Indonesia. Adapun Hak memilih menurut Kamus Besar Bahasa Indonesia adalah hak untuk memilih calegpada penyelenggaraan pemilu, hak untuk menyuarakan pendapat terhadap masalah politik, khususnya hak atau kekuasaan untuk mengambil bagian untuk memilih atau menolak rencana peraturan/undang-undang. ${ }^{11}$ Masih Menurut Kamus Besar Bahasa Indonesia, Hak dipilih adalah hak untuk dipilih dalam pemilu untuk menjadi anggota DPR atau MPR. ${ }^{12}$

Secara umum, pengertian Hak Asasi Manusia terdapat pada UU HAM yang menyatakan Hak Asasi Manusia adalah suatu susunan hak yang dikarenakan kodrat dan keberadaan manusia sebagai makhluk ciptaanTuhan Yang Maha Esa serta merupakan anugerah-Nya yang wajib dihormati, dijunjung tinggi dan dilindungi oleh negara, hukum, Pemerintah, dan setiap orang demi kehormatan serta perlindungan harkat dan martabat manusia. Tetapi secara khusus Hak asasi manusia dalam hal ini Hak Memilih dan Dipilih merupakan hak yang diatur dalam kovenan hak sipil dan politik sebagaimana diatur dalam UU ICCPR. Hak sipil politik adalah hak yang dimiliki setiap warga negara ketika berhadapan dengan suatu negara yang memiliki kedaulatan, hak-hak yang dimiliki warga negara sebagai warga sipil dalam sebuah negara dan juga hak politik berupa equity before the law, tidak ada diskriminasi dan sebagainya dalam kedudukannya sebagai warga negara maupun sebagai subjek

\footnotetext{
11 Departemen Pendidikan Nasional, 2012, Kamus Besar Bahasa Indonesia, Pusat Bahasa (Edisi Keempat), PT. Gramedia Pustaka Utama, Jakarta, hlm. 474-475.

12 Ibid., hlm. 474.
} 
hukum. Vierdag mengkategorikan hak sipil dan politik ini sebagai hak negatif (negativeright) karena untuk merealisasikannya negara haruspasif, tidak melakukan tindakan, oleh karenanya definisinya menggunakan freedom from (bebas dari). ${ }^{13}$

\subsection{Pengaturan dan Perlindungan Terhadap Hak Memilih dan Dipilih terhadap Pidana Tambahan Pencabutan Hak Memilih dan Dipilih}

Sebagaimana diketahui bahwa hak asasi manusia secara tegas diatur dalam pasal 1 ayat (1) UU HAM.

Undang-undang perlindungan HAM sebenarnya telah melindungi hak memilih dan dipilih tersebut baik melalui UU HAM pada Pasal 23 ayat (1), Pasal 26 ayat (2), Pasal 43 ayat (1), Pasal 73 dan 74 yang pada intinya menegaskan:

- Setiap orang bebas untuk memilih dan mempunyai keyakinan politiknya.

- Setiap warga negara berhak untuk dipilih dan memilih dalam pemilu sesuai dengan ketentuan peraturan perundang-undangan.

- Hak dan kebebasan yang diatur dalam undang-undang ini hanya dapat dibatasi oleh dan berdasarkan undang-undang demi ketertiban umum dan kepentingan bangsa.

13 Mahrus Ali dan Syarif Nurhidayat, 2011, Penyelesaian Pelanggaran HAM BERAT In Court System \& Out Court System, Gramata Publishing, Depok, hlm. 9.
Tidak satu ketentuan pun dalam undang-undang ini boleh diartikan bahwa Pemerintah, partai, golongan atau pihak manapun dibenarkan mengurangi, merusak, atau menghapuskan HAM atau kebebasan dasar yang diatur dalam undang-undang.

Juga terdapat pada pasal $28 \mathrm{D}$ ayat (3) UUD 1945 yang menyatakan: setiap warga negara berhak memperoleh kesempatan yang sama dalam pemerintahan

Adapun UU ICCPR mengatur antara lain:

Pasal 4 UU ICCPR menyatakan:

1. Dalam keadaan darurat...yang telah diumumkan secara resmi, negara-negara pihak kovenan ini dapat mengambil langkahlangkah yang mengurangi kewajiban-kewajiban mereka berdasarkan kovenan ini...

2. Setiap negara pihak kovenan ini yang menggunakan hak untuk melakukan pengurangan tersebut harus segera memberitahukannya kepada Negara-negara pihak lainnya melalui perantaraan Sekretaris Jenderal Perserikatan Bangsa-bangsa...

Pasal 5 UU ICCPR menyatakan:

1. Bahwa tidak ada satu ketentuan pun dalam Kovenan ini yang dapat ditafsirkan sebagai memberi hak kepada negara... bertujuan menghancurkan hak atau kebebasan mana pun yang 
diakui dalam Kovenan ini atau membatasinya...

2. Tidak diperkenankan adanya suatu pembatasan atau penyimpangan HAM mendasar yang diakui...

Pasal25 UU ICCPR menyatakan: hak setiap warga negara untuk ikut serta dalam penyelenggaraan urusan publik, untuk memilih dan dipilih...

Dalam pada itu pencabutan hak memilih dan dipilih mendapat legitimasi dari KUHP jo., UU PTPK yang pengaturannya antara lain:

Pasal 10 KUHP huruf $b$ yang menegaskan pidana Pencabutan hak-hak tertentu.

Selanjutnya Pasal 35 ayat (1) KUHP menegaskan:

Hak-hak terpidana yang dengan putusan hakim dapat dicabut dalam hal-hal yang ditentukan dalam kitab Undang-undang ini, atau dalam aturan umum lainnya ialah salah satunya pada nomor 3 adalah Hak memilih dan dipilih dalam pemilihan yang diadakan berdasarkan aturan-aturan umum; UU PTPK yakni:

Pasal 18 ayat (1) huruf d menyatakan:

Selain pidana tambahan dimaksud dalam Kitab Undangundang Hukum Pidana sebagai pidana tambahan adalah:

Pencabutan seluruh atau sebagian hak-hak tertentu atau penghapusan atau sebagian keuntungan tertentu, yang telah atau dapat diberikan oleh Pemerintah kepada terpidana.
Terhadap konflik norma tersebut maka berlakulah asas-asas penyelesaian konflik (asas preferensi hukum), yaitu:

$\begin{array}{rrr}\text { 1. Lex superiori } & \text { derogat } \\ \text { legi } & \text { inferiori, } & \text { yaitu }\end{array}$ peraturan perundang-undangan yang lebih tinggi kedudukannya akan melumpuhkan peraturan perundang-undangan yang lebih rendah kedudukannya;

2. Lex specialis derogat legi generali, yaitu peraturan yang khusus akan melumpuhkan peraturan yang umum sifatnya atau peraturan yang khususlah yang harus didahulukan;

3. Lex posteriori derogat legi priori, yaitu peraturan yang baru mengalahkan atau melumpuhkan peraturan yang lama. ${ }^{14}$

Disamping asas preferensi diatas, masih ada tipe penyelesaian berkaitan dengan asas preferensi hukum, adalah Reinterpretasi yaitu dengan mengikuti asas-asas preferensi, menginterpretasi kembali norma yang utama dengan cara yang lebih fleksibel. Cara yang kedua dengan menginterpretasi norma preferensi dan kemudian menerapkan norma tersebut dengan menyampingkan norma yang lain. ${ }^{15}$

Oleh karena terdapat konflik norma antara UU ICCPR jo., UU HAM terhadap KUHP jo., UU PTPK maka

14 Sudikno Mertokusumo, 2002, Mengenal Hukum (Suatu Pengantar), Cetakan Ketiga, Liberty, Yogyakarta, hlm. 85-87.

15 Philipus M. Hadjon dan Tatiek Sri Djatmiati, 2009, Argumentasi Hukum, Gadjah Mada University Press, Yogyakarta, hlm. 31-32. 
dengan menggunakan asas preferensi hukum berupa peraturan yang baru mengalahkan atau melumpuhkan peraturan yang lama, oleh karenanya seharusnya KUHP jo., UU PTPK semestinya sudah tergantikan dan tidak berlaku lagi setelah berlakunyaUU ICCPRjo., UU HAM. Hal ini didukung juga dengan metode reinterpretasi dengan cara kedua sebagaimana dijelaskan di atas yakni dengan menginterpretasi norma preferensi dan kemudian menerapkan norma tersebut dengan menyampingkan norma yang lain oleh karena norma yang dikesampingkan tersebut tidak lagi memiliki daya laku dan daya guna karena sudah tergantikan dengan norma yang baru. Dalam hal ini yang disampingkan adalah KUHP jo., UU PTPK juga dikarenakan adanya syarat yang diwajibkan dalam UU ICCPR yang harus dipenuhi agar pengurangan apalagi pencabutan terhadap HAM seseorang dapat dilakukan oleh pemerintah.

Pasal 28 D UUD 1945 seolah mempertegaskan hal tersebut, yang mana menyatakan pengakuan, jaminan, perlindungan dan kepastian hukum yang adil atas setiap orang serta pengakuan yang sama di hadapan hukum.

Inti paham HAM adalah Pertama,bahwa HAM secara kodrati inheren atau melekat, universal mengacu bahwa HAM itu tanpa adanya pembedaan ras,...dan status sosial lainnya serta tidak dapat dicabut; hak-hak itu dimiliki karena mereka adalah manusia sebagai makhluk ciptaan Tuhan, bukan karena mereka adalah warga negara suatu negara. Kedua, perlindungan efektif terhadap HAM terdapat dalam kerangka batasbatas legitimasi yang demokratis. Ketiga,batas-batas pelaksanaan HAM hanya dapat ditetapkan atau dicabut oleh undang-undang sebagai bagian dari konsep negara hukum yang bermakna bahwa hak harus dilindungi oleh undang-undang, dan bahwa ketika mencabut atau mengurangi hak-hak individu, pemerintah wajib mematuhi persyaratan hukum yang konstitusional.

Konsepsi ini juga mengharuskan pemerintah bertindak sesuai dengan undang-undang, dan undang-undang yang dijadikan dasar tindakan pemerintah itu tidak bersifat menindas, tidak diskriminatif atau sewenangwenang. Dengandemikian pelaksanaan hak-hak kodrati setiap manusia tidak dibatasi kecuali oleh batas-batas yang menjamin pelaksanaan hak-hak yang sama bagi anggota masyarakat yang lain.

Hal tersebut sejalan dengan Teori Kedaulatan Hukum (rechtssouvereiniteit) bahwahukum diatas dari segala kekuasaan. Oleh karenanya baik raja atau penguasa, rakyat, maupun negara itu sendiri semuanya tunduk pada hukum. Pemuka Teori Kedaulatan Hukum ini salah satunya adalah H. Krabbe yang menyatakan bahwa yang memiliki kekuasaan tertinggi dalam negara adalah hukum. Paham Krabbe tersebut dipengaruhi oleh aliran historis yang 
dipelopori oleh von Savigny yang menyatakan bahwa hukum timbul bersama-sama kesadaran hukum masyarakat. Hukum tidak timbul dari kehendak/kemauan negara. Dengan demikian, berlakunya hukum terlepas dari kemauan negara. H. Krabbe menghendaki agar negara seharusnya negara hukum (rechtsstaat) dan setiap tindakan negara harus didasarkan pada hukum atau harus dapat dipertanggungjawabkan menurut hukum. ${ }^{16}$ Demikian juga dengan keberlakuan UU ICCPR yang semestinya dipakai sebagai acuan dalam memberikan putusan bagi lembaga yudikatif atau terhadap Pemerintah dalam menentukan kebijakan guna mewujudkan Indonesia sebagai negara hukum yang bebas dari korupsi, kolusi dan nepotisme.

\subsection{Pertimbangan Majelis Hakim Kasasi Dalam Memberikan Pidana Tambahan Berupa Pencabutan Hak Memilih Dan Dipilih Terhadap Ratu Atut Chosiyah}

Dasar pertimbangan Majelis Hakim pada tingkat Kasasi terhadap pemberian pidana tambahan berupa pencabutan hak memilih dan dipilih terhadap Ratu Atut Chosiyah antara lain sebagai berikut:

- Walaupun seorang Terdakwa telah dijatuhi pidana penjara oleh Pengadilan, tidak semua

Ishaq, 2012, Dasar-dasar Ilmu Hukum, Sinar Grafika, Jakarta, hlm. 205. lapisan masyarakat mengetahui khususnya di pedesaan, sehingga jika Terdakwa telah selesai menjalani pidana maka bisa saja yang bersangkutan kembali ke kancah politik atau menjadi pejabat publik dan masyarakat yang tidak mengetahui hal tersebut akan memilihnya kembali. Di samping itu, sesuai dinamika perkembangan politik di Indonesia yang perubahannya begitu cepat maka orang-orang politik yang telah dipidana karena melakukan kejahatan khususnya perkara Korupsi, bisa menyusun kekuatan untuk membuat peraturan perundangundangan yang menguntungkan bagi mereka untuk bisa terjun kembali ke kancah politik;

Bahwa mengenai penjatuhan pidana tambahan berupa pencabutan hak memilih dan dipilih telah terbukti dan diterima/dikabulkan oleh Mahkamah Agung RI melalui beberapa putusan antara lain perkara atas nama Terdakwa LUTHFI HASAN ISHAAQ dan atas nama Terdakwa DJOKO SUSILO. Hal ini menunjukkan bahwa satu-satunya cara untuk membuat jera para pelaku tindak pidana Korupsi di bidang politik selain pemberatan pidana adalah melalui putusan Pengadilan yang mencabut hak Terdakwa untuk memilih dan dipilih; 
Selanjutnya pertimbangan mengenai tidak didakwakannya ketentuan Pasal 18 ayat (1) huruf d UU No. 31 Tahun 1999 dalam dakwaan menjadi alasan tidak dijatuhkannya pidana tambahan tersebut, menurut pendapat Majelis Hakim tingkat Kasasi juga tidak benar, karena ketentuan Pasal 18 ayat (1) huruf d tersebut merupakan ketentuan umum yang telah mengikat dan berlaku pada setiap tindak pidana Korupsi. Selain itu Pasal 18 ayat (1) huruf d tersebut adalah ketentuan tentang Penjatuhan Pidana Tambahan yang bukan ketentuan tentang perbuatan / tindak pidana sehingga tidak harus dicantumkan dalam dakwaan;

- Berdasarkan uraian tersebut di atas, maka kepada Terdakwa selaku politikus senior dan sekaligus sebagai Penyelenggara Negara sudah selayaknya dijatuhi pidana tambahan berupa pencabutan seluruh atau sebagian hak-hak tertentu yaitu "pencabutan hak untuk memilih dan dipilih dalam jabatan publik", karena Terdakwa telah mencederai nilai-nilai dari demokrasi itu sendiri;

- Walaupun pembentuk Undang-Undang, Doktrin dan Yurisprudensi tidak memberikan pegangan pada Hakim dalam menetapkan berat ringannya hukuman yang akan dijatuhkan kepada Terdakwa, sehingga Hakim mempunyai kebebasan dalam menetapkan atau menjatuhkan hukuman (pidana), maka sepatutnyalah Majelis Hakim menjatuhkan pidana tidak hanya untuk kepentingan pembinaan Terdakwa semata, melainkan seharusnya Majelis Hakim juga memperhatikan kepentingan Masyarakat dan Negara;

Bahwa dalam perkara a quo Terdakwa diajukan ke depan persidangan karena didakwa melakukan perbuatan memberikan uang (menyuap) sebesar Rp1.000. 000.000,00 (satu miliar rupiah) kepada $\mathrm{M}$. AKIL MOCHTAR melalui SUSI TUR ANDAYANI terkait perkara PHPU-D Kabupaten Lebak Provinsi Banten Tahun 2013, sehingga perbuatan Terdakwa telah menciderai Lembaga Mahkamah Konstitusi dan menodai demokrasi serta hak-hak rakyat. Lebih jauh perbuatan Terdakwa dapat menyebabkan terpilihnya Kepala Daerah yang Korup; Bahwa perbuatan Terdakwa tersebut sesungguhnya merupakan tindak pidana yang sangat serius, dan oleh karenanya sejalan dengan semangat untuk melakukan pemberantasan Korupsi dengan "extra ordinary methode", 
maka seharusnya pidana yang dijatuhkan tidak terlalu ringan;

Bahwa oleh karena itu, setiap perbuatan memberi atau menjanjikan sesuatu kepada Hakim Mahkamah Konstitusi, dengan maksud untuk mempengaruhi putusan perkara yang diserahkan kepadanya untuk diadili, adalah suatu perbuatan yang secara langsung dapat merusak tatanan, harkat dan martabat bangsa dan Negara RI; 6 Bahwa Pemohon Kasasi II/Terdakwa sebagai seorang Gubernur/ Kepala Daerah justru harus pula menjadi pengawal Konstitusi dan bukan merusaknya dengan cara mempengaruhi Hakim Mahkamah Konstitusi dengan memberi atau menjanjikan sesuatu agar memutus perkara sesuai kehendak Pemohon Kasasi II/ Terdakwa;

- Bahwa judexfacti salah menerapkan ketentuan hukum terkait peran serta Pemohon Kasasi II/Terdakwa dalam hal pemberian uang kepada Hakim M. Akil Mochtar. Walaupun Pemohon Kasasi II/Terdakwa bukan pelaku yang memenuhi semua anasir-anasir peristiwa pidana, tetapi tanpa turut sertanya Pemohon Kasasi II/Terdakwa maka peristiwa pidana berupa pemberian janji dan hadiah kepada Hakim M. Akil Mochtar tidak akan terjadi;
Bahwa judexfacti tidak mempertim-bangkan dengan benar hal-hal yang relevan secara yuridis, yaitu perbuatan Terdakwa yang menjabat sebagai Gubernur Banten bersifat aktif untuk mempengaruhi M. Akil Mochtar untuk memenangkan perkara yang diproses di Mahkamah Konstitusi;

Bahwa perbuatan Terdakwa selaku pemegang kekuasaan politik telah melakukan Korupsi politik dan mempengaruhi Hakim Mahkamah Konstitusi sehingga perlu dijatuhi pidana yang setimpal dengan sifat berbahayanya kejahatan yang dilakukan;

Bahwa agar perbuatan Pemohon Kasasi II/Terdakwa sebagai Pimpinan yang seharusnya menjadi tauladan, tidak terulang di kemudian hari maka kemungkinanterpilihnyakembali yang bersangkutan dalam jabatan publik haruslah dicegah, oleh karena itu keberatan Pemohon Kasasi I/Penuntut Umum pada Komisi Pemberantasan Korupsi sepanjang mengenai penerapan hukuman tambahan berupa pencabutan hak tertentu untuk dipilih dalam jabatan publik, dapat diterima; ${ }^{17}$

Putusan No. 285K/Pid.Sus/2015 tertanggal 23 Februari 2015, diakses tanggal 10 November 2015, pukul 09.36, terdapat pada: http:// putusan.mahkamahagung.go.id/putusan/fba96 cb88e1fb06568ef5202cd295334, hlm. 67-75. 
Meski dalam pertimbangan tersebut telah menyebutkan bahwa upaya pencegahan dan pemberantasan Korupsi perlu semakin ditingkatkan dan diintensifkan dengan tetap menjunjung tinggi hak asasi manusia dan kepentingan masyarakat tetapi tidak satupun undang-undang maupun pasal dalam UUHAM atau UU ICCPR diakomodir dalam pertimbangan putusan Mahkamah Agung tersebut. Sehingga dalam pertimbangan Majelis Hakim tingkat kasasi terhadap putusan Ratu Atut Chosiyah tersebut menggunakan asas preferensi hukum lexspecialis derogate legigenerali yakni dengan mengesampingkan UU yang berkaitan dengan HAM dengan memberlakukan Pasal 18 ayat (1) huruf d UU HAM sebagai dasar hukum khusus pada tindak pidana korupsi dalam hal pencabutan hak memilih dan dipilih terhadap Ratu Atut Chosiyah.

\subsection{Eksistensi Keadilan Dalam Putusan Pencabutan Hak Memilih dan Dipilih Ratu AtutChosiyah}

Dalam menganalisis putusan Kasasi terhadap pencabutan hak memilih dan dipilih Ratu Atut Chosiyah terlebih dahulu harus diketahui mengenai parameter keadilan tersebut, keadilan menurut Gustav Radbruch:

keadilan terarah pada rechtsidee. Keadilan sebagai suatu cita, seperti ditunjukkan oleh Aristoteles, tidak dapat mengatakan lain kecuali: 'yang sama diperlakukan sama, dan yang tidak sama diperlakukan tidak sama'. Untuk mengisi cita keadilan ini dengan isi yang konkret, kita harus menengok pada segi finalitasnya. Jadi bagi Radbruch, hukum memiliki tiga aspek, yakni keadilan, finalitas dan kepastian. Aspek keadilan menunjuk pada 'kesamaan hak di depan hukum'. Aspek finalitas, menunjuk pada tujuan keadilan, yaitu memajukan kebaikan dalam hidup manusia. Aspek ini menentukan isi hukum. Sedangkan kepastian menunjuk pada jaminan bahwa hukum (yang berisi keadilan dan norma-norma yang memajukan kebaikan), benar-benar berfungsi sebagai peraturan yang ditaati. Dapat dikatakan, dua aspek yang disebut pertama merupakan kerangka ideal dari hukum. Sedangkan aspek ketiga (kepastian merupakan kerangka operasional hukum). ${ }^{18}$

Terhadap pengertian keadilan tersebut maka dapat diambil suatu kesimpulan bahwa keadilan harus memuat kerangka ideal dari hukum dan kerangka operasional dari hukum, kerangka ideal memuat kesamaan setiap individu di hadapan hukum dan tujuan daripada hukum itu adalah untuk mewujudkan kebaikan dan kesejahteraan. Sedangkan

18 Bernard L. Tanya, Dkk., 2010, Teori Hukum (Strategi Tertib Manusia Lintas Ruang dan Generasi), Genta Publishing, Yogyakarta, hlm. 129. 
kerangka operasional hukum yakni berupa jaminan agar kerangka ideal tersebut dapat dipatuhi oleh seluruh masyarakat. Dalam kerangka putusan kasasi pencabutan hak memilih dan dipilih terhadap Ratu AtutChosiyah juga terdapat kerangka ideal dari hukum yakni si terpidana dianggap sama di hadapan hukum, tanpa mengenal jabatannya tetapi oleh karena jabatannya sebagai pejabat publik yang merupakan hasil daripada pemilu maka dalam hal ini dia disatu sisi dikhususkan dalam hal pemberian hukumannya. Norma-norma yang berisi keadilan dan yang memajukan kebaikan terdapat pada KUHP dan UU PTPK yang mana mengatur mengenai pencabutan hak memilih dan dipilih di samping itu juga terdapat UU ICCPR dan UU HAM yang juga mengandung unsur keadilan dan kebaikan tetapi melarang pencabutan hak memilih dan dipilih.

Konflik norma tersebut di atas telah diselesaikan dengan asas lex posterior derogate legiinferiori dimana UU ICCPR dan UU HAM mesti dikedepankan daripada KUHP dan UU PTPKdikarenakan UU ICCPR jo., UU HAM berlaku belakangan dibandingkan UU yang lain. Berdasarkan hal ini, kerangka hukum yang ideal adalah kerangka hukum yang berdasarkan atas UU ICCPR jo., UU HAM dimana pencabutan hak memilih dan dipilih tidak boleh diberlakukan bagi setiap orang, baik terdakwa pada kasus korupsi maupun terhadap kasus tindak pidana lain yang berhubungan dengan penyalahgunaan kekuasaan/kewenangan pejabat publik, sehingga dengan kata lain pencabutan hak memilih dan dipilih terhadap Ratu Atut Chosiyah tidak mencerminkan keadilan karena tidak sesuai dengan kerangka ideal dari keadilan Gustav Radbruch. Putusan pencabutan hak memilih dan dipilih ini murni berasal dari kewenangan lembaga yudikatif yang bebas dalam memberikan dan menjatuhkan putusan tanpa memperhatikan keberlakuan, fungsi dan tujuan hukum itu sendiri.

Ketika lembaga yudikatif secara bebas menggunakan kewenangannya untuk mencabut hak memilih dan dipilih tanpa berlandaskan atas keadilan, kebenaran dan kepastian hukum maka disanalah terdapat kesewenang-wenangan/abuse ofpower dikarenakan hakim dalam menjatuhkan putusan hanya berdasarkan pada unsur subjektifnya tanpa memikirkan keberlangsungan dan kepentingan rakyat banyak di dalamnya.Tetapi hakim tidak sepenuhnya bersalah dalam hal ini, pemerintah juga memegang andil dalam menciptakan kekacauan terhadap rasa keadilan.

Pengumuman daruratmerupakan kewenangan Presiden yang telah diatur dalam Pasal 12 UUD 1945 yang menyatakan "Presiden menyatakan keadaan bahaya, syarat-syarat dan akibatnya keadaan bahaya diatur dalam undang-undang". Hal ini juga diatur dalam Pasal 2 ayat (2) Perpu 
No. 23 Tahun 1959 yang menyatakan: "Pengumuman pernyataan atau penghapusan keadaan bahaya dilakukan oleh Presiden".

Selaras dengan UUD 1945 jo., Perpu 23/1959 tersebut di atas, UU ICCPR dan UU HAM juga mewajibkan kepada Presiden agar seseorang dapat dicabut hak memilih dan dipilihnya sebelumnya harus diumumkan mengenai keadaan darurat khususnya darurat korupsi hal mana juga mesti dilaporkan kepada Sekjen PBB perihal pengumuman darurat tersebut untuk disampaikan kepada anggota-anggota PBB lainnya bahwa suatu negara sedang dalam fase darurat korupsi. Apabila lembaga yudikatif serta merta mengesampingkan syaratsyarat UU ICCPR dan UU HAM ini maka otomatis pemerintah telah melemparkan tanggung jawabnya dalam pemberantasan korupsi hanya kepada lembaga yudikatif yang tidak banyak membantu memenuhi rasa keadilan sosial.

Faktanya, putusan pidana tambahan pencabutan hak memilih dan dipilih saat ini hanya diberikan oleh Mahkamah Agung dan spesifik dari hakim tertentu yang terbatas masa kerjanya. Bandingkan apabila darurat korupsi diberlakukan, kemungkinan perkembangan terhadap proses penyelidikan, penyidikan, penuntutan, pembuktian dan sanksi/ pemidanaan dari tersangka, terdakwa maupun terpidana korupsi baik di tahap pengadilan negeri, pengadilan tinggi maupun mahkamah agung dapat berkembang secara signifikan ke arah yang lebih memihak kepentingan rakyat banyak. Sedangkan aspek kepastian hukum yang menjamin agar kerangka ideal dari hukum berupa keadilan dan finalitas dapat berjalan juga mendapat kendala dikarenakan selama ini kerangka ideal yang berjalan tidak memenuhi unsur keadilan bagi seluruh rakyat Indonesia sebagaimana terkandung dalam sila ke-5 Pancasila.

\section{PENUTUP}

\subsection{Simpulan}

1. Putusan pemberian pidana tambahan berupa pencabutan hak memilih dan dipilih sebagai pidana tambahan adalah tidak sesuai dengan teori kedaulatan hukum, asas Lex posteriori derogat legi priori dan perlindungan Hak Asasi Manusia di Indonesia sehingga cenderung putusan tersebut cacat hukum dan prematur dikarenakan masih terdapat konflik norma antara UUHAM jo., UU ICCPR dengan KUHP jo., UU PTPK yang mana sebenarnya UU ICCPR yang mestinya di dahulukan daripada UU PTPK dikarenakan selain UU ICCPR berlaku belakangan daripada UU PTPK. UU ICCPR telah mengharuskan untuk mengumumkan keadaan darurat korupsi agar hak memilih dan dipilih dapat dicabut. Selain itu, UU ICCPR juga mengatur secara 
khusus mengenai hak memilih dan dipilih tersebut.

2. Pemberian pidana tambahan berupa pencabutan hak memilih dan dipilih terhadap Ratu Atut Chosiyah masih belum memenuhi rasa keadilan bagi seluruh rakyat Indonesia. Hal ini dikarenakan dalam UU ICCPR dan UU HAM telah mengatur mengenai syarat pencabutan hak memilih dan dipilih yakni pengumuman darurat suatu negara dalam hal ini darurat korupsi. Apabila pemerintah/ Presiden RI konsekuen untuk menjadi panglima terdepan dalam pemberantasan korupsi dari hulu ke hilir maka sudah seharusnya syarat UU ICCPR dan UU HAM tersebut dipenuhi agar keadilan dapat terwujud di semua sendi kehidupandan diharapkan kedepannya rasa keadilan sosial yang mengarah ke kesejahteraan sosial dapat terwujud di Indonesia.

\subsection{Saran}

1. Hendaknya pemerintah dalam hal ini lembaga eksekutif, legislatif dan yudikatif bekerja sama secara terstruktur dan terintegrasi dalam pengakuan, perlindungan dan penegakan HAM yang berdasarkan atas kebenaran, keadilan, kepastian hukum serta berlandaskan Pancasila dan UUD 1945.
Hal ini dapat terwujud apabila pengumuman darurat korupsi oleh eksekutif yakni Presiden agar syarat Pasal 4 dan Pasal 5 UU ICCPR dapat dipenuhi sehingga penjatuhan pidana tambahan berupa pencabutan hak memilih dan dipilih terhadap terpidana khususnya terpidana korupsi yang dilakukan oleh lembaga yudikatif tidak cacat hukumserta tidak selektif hanya diberikan oleh hakim tertentu maupun pada tingkat peradilan tertentu. Lembaga legislatif pun mestinya memberikan terobosan baru dan mendukung lewat regulasi perihal penegakan dan pemberantasan tindak pidana korupsi.

2. Keadilan sosial sebagaimana terdapatdalamsilake-VPancasila dan UUD 1945 serta yang selaras dengan teori keadilan Gustav Radbruch adalah keadilan yang mengakomodirkeadilan, finalitas dan kepastian hukum, oleh karenanya untuk mewujudkan keadilan sosial tersebut maka tidak saja dibutuhkan peran aktif dari lembaga yudikatif, tetapi juga lembaga eksekutif, legislatif juga peran aktif dari seluruh komponen rakyat Indonesia dalam rangka pemberantasan tindak pidana korupsi agar kesejahteraan sosial bagi seluruh rakyat Indonesia dapat terwujud. 


\section{DAFTAR PUSTAKA}

\section{Buku}

Ali, Mahrus dan Nurhidayat, Syarif, 2011,Penyelesaian Pelanggaran

HAM BERAT In Court System \& Out Court System, Gramata Publishing, Depok.

Armia, Muhammad SiddiqTgk., 2008, Perkembangan Pemikiran

Teori Ilmu Hukum, PT. PradnyaParamita, Jakarta.

Departemen Pendidikan Nasional, 2012, Kamus Besar Bahasa Indonesia, Pusat Bahasa (Edisi Keempat), PT. Gramedia Pustaka Utama, Jakarta.

Effendi, Masyur, 2012, Dimensi/ Dinamika Hak Asasi Manusia Dalam Hukum Nasional dan Internasional, Ghalia Indonesia, Jakarta.

Dworking, Ronald, 1973, Legal Research, Daendalus, h. 250, dalam YentiGarnasih, 2003, Kriminalisasi Pencucian Uang (Money Laundering), Program Pasca Sarjana Fakultas Hukum Universitas Indonesia, Jakarta.

Hadjon, Philipus M. dan Djatmiati, Tatiek Sri, 2009, Argumentasi Hukum, Gadjah Mada University Press, Yogyakarta.

Hamzah, Andi, 2005, Pemberantasan Korupsi Melalui Hukum Pidana Nasional dan Internasional, Raja Grafindo Persada, Jakarta. Ishaq, 2012, Dasar-dasar Ilmu Hukum, Sinar Grafika, Jakarta.
Mertokusumo, Sudikno, 2002, Mengenal Hukum (Suatu Pengantar), Cetakan Ketiga, Liberty, Yogyakarta.

ND, MuktiFajardanAchmad, Yulianto, 2007, Dualisme Penelitian Hukum, Fakultas Hukum Universitas Muhammadiyah, Yogyakarta.

Sidharta, B. Arief, 2009, Meuwissen Tentang Pengembanan Hukum, Ilmu Hukum dan Filsafat Hukum, PT. Refika Aditama, Bandung.

Scott, Davidson, 2008, Hak Asasi Manusia: Sejarah, Teori Dan Praktek Dalam Pergaulan Internasional Terjemahan A. Hadnyana Pudjaatmaka, Grafiti, Jakarta.

Tutik, Titik Triwulan, 2006, Pengantar Ilmu Hukum, Prestasi Pustaka, Jakarta.

Wisnubroto Al. danWidiartana, G., 2005, Pembaharuan Hukum Acara Pidana, PT. Citra Aditya Bakti, Bandung.

\section{UNDANG-UNDANG}

Undang-undang Dasar Negara Republik Indonesia Tahun 1945;

Undang-undang No. 1 Tahun 1946 Tentang KUHP;

Undang-undang No. 31 Tahun 1999 Tentang Pemberantasan Tindak Pidana Korupsi;

Undang-undang No. 39 Tahun 1999

Tentang Hak Asasi Manusia; 
Undang-undang No. 12 Tahun 2005 Tentang Pengesahan International Covenant on Civil and Political Rights;

Undang-undang No. 8 Tahun 2012 Tentang Pemilihan Umum Anggota DPR, DPD dan DPRD.

\section{INTERNET}

Putusan No. 285K/Pid.Sus/2015 tertanggal 23 Februari 2015, diakses tanggal 10 November 2015, pukul 09.36, terdapat pada: http://putusan. mahkamahagung.go.id/putusan/fba96 cb88e1fb06568ef5202cd295334. 